\title{
Pengembangan LKS Biologi SMA Berbasis Praktikum dengan Model Pembelajaran Langsung untuk Meningkatkan Keterampilan Proses Sains Siswa
}

\author{
${ }^{*}$ Baiq Mirawati, 2 Ida Royani \\ 1\&2Program Studi Pendidikan Biologi, Universitas Pendidikan Mandalika \\ (UNDIKMA), Jl. Pemuda No. 59A Mataram 83125, Indonesia \\ *Email Korespondensi: baiqmirawati@ikipmataram.ac.id
}

\begin{tabular}{|c|c|}
\hline Article Info & Abstract \\
\hline $\begin{array}{l}\text { Article History } \\
\text { Received: October } 2019 \\
\text { Revised: November } 2019 \\
\text { Published: December } 2019\end{array}$ & \multirow{2}{*}{$\begin{array}{l}\text { [Title: Development of Student Worksheets based on Practicum with Direct } \\
\text { Learning Models to Improve Students' Science Process Skills]. This research aims } \\
\text { to develop student worksheets based on practicum with direct learning models that valid, } \\
\text { practical and effective to improve students' science process skills. This research is a } \\
\text { development study using } 4 D \text { stages with the subject of } 30 \text { students of class X1 IPA1 } \\
\text { MAPK Syeh Zainuddin Anjani. The developed student worksheet was validated by three } \\
\text { competent validators using validation sheets. The practicalities of the worksheets } \\
\text { developed were measured using student response questionnaires, while the effectiveness } \\
\text { of worksheets was measured using an observation sheet of students' science process skills } \\
\text { by two observers. Research data were analyzed descriptively and quantitatively. The } \\
\text { results showed that the student worksheets with tissue culture material were quite valid } \\
\text { (a score of 3.9), the students' responses after learning showed a high percentage with a } \\
\text { very strong category (81\%-100\%), while the students' process skills improved at each } \\
\text { meeting in the good category. Based on the results of the study, it can be concluded that } \\
\text { the student worksheets based on practicum with direct learning models were valid, } \\
\text { practical, and effective to improve the students' science process skills of MAPK Syeh } \\
\text { Zainuddin Anjani. }\end{array}$} \\
\hline $\begin{array}{l}\text { Key } \\
\text { Stuc } \\
\text { Dire } \\
\text { Scie }\end{array}$ & \\
\hline Info & 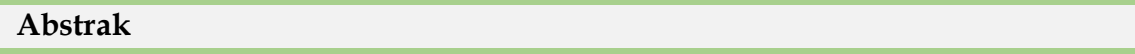 \\
\hline $\begin{array}{l}\text { Sejar } \\
\text { Diter } \\
\text { Direv } \\
\text { Dipul } \\
2019\end{array}$ & \multirow{2}{*}{$\begin{array}{l}\text { Penelitian ini bertujuan untuk mengembangkan LKS biologi SMA berbasis } \\
\text { praktikum dengan model pembelajaran langsung yang valid, praktis, dan efektif } \\
\text { untuk meningkatkan keterampilan proses sains siswa. Penelitian ini merupakan } \\
\text { penelitian pengembangan menggunakan tahapan 4D dengan subjek } 30 \text { siswa } \\
\text { kelas X1 IPA } 1 \text { MAPK Syeh Zainuddin Anjani. LKS yang dikembangkan } \\
\text { divalidasi oleh tiga orang validator yang berkompeten menggunakan lembar } \\
\text { validasi. Kepraktisan LKS yang dikembangkan diukur menggunakan angket } \\
\text { respon siswa, sedangkan keefektifan LKS diukur menggunakan lembar } \\
\text { observasi keterampilan proses sains siswa oleh dua orang pengamat. Data hasil } \\
\text { penelitian dianalisis secara deskriptif-kuantitatif. Hasil penelitian menunjukkan } \\
\text { bahwa LKS Biologi SMA materi kultur jaringan cukup valid (skor 3,9), respon } \\
\text { siswa setelah pembelajaran menunjukkan persentase tinggi dengan kategori } \\
\text { sangat kuat (81\%-100\%), sedangkan keterampilan proses siswa meningkat pada } \\
\text { setiap pertemuan dengan kategori sangat baik. Berdasarkan hasil penelitian } \\
\text { dapat disimpulkan bahwa LKS Biologi SMA berbasis praktikum dengan model } \\
\text { pembelajaran langsung valid, praktis, dan efektif untuk meningkatkan } \\
\text { keterampilan proses sains siswa MAPK Syeh Zainuddin Anjani. }\end{array}$} \\
\hline $\begin{array}{l}\text { Kata kunci } \\
\text { LKS; } \\
\text { Pembelajaran lar } \\
\text { Keterampilan pr }\end{array}$ & \\
\hline How & $\begin{array}{l}\text { Mirawati, B., \& Royani, I. (2019). Pengembangan LKS Biologi SMA Berbasis } \\
\text { Praktikum dengan Model Pembelajaran Langsung untuk Meningkatkan } \\
\text { Keterampilan Proses Sains Siswa. Jurnal Penelitian dan Pengkajian Ilmu Pendidikan: } \\
\text { e-Saintika, 3(2), 88-95. DOI: https:// doi.org/10.36312/e-saintika.v3i2.152 }\end{array}$ \\
\hline
\end{tabular}




\section{PENDAHULUAN}

Berkembangnya K-13 dilandasi pemikiran untuk peningkatan pendidikan pada abad 21 salah satu tantangan yang dihadapi adalah ditandai dengan abad ilmu pengetahuan, knowledge-based society dan kompetensi masa depan. Kurikulum K-13 menekankan pada tiga aspek kompetensi yang harus dimiliki oleh siswa yaitu sikap, pengetahuan dan keterampilan yang diharapkan mampu membuat siswa memiliki kompetensi sikap, pengetahuan dan keterampilan. Kompetensi tersebut dapat dicapai dengan utuh dalam kurikulum K-13 yang menekankan pada penggunaan pendekatan ilmiah pada proses pembelajaran (Kemendikbud, 2013). Implementasi teori yang diperoleh siswa di kelas, dapat dilakukan di laboratorium dalam bentuk kegiatan praktikum. Berbagai perangkat keras dan perangkat lunak berupa program pembelajaran telah tersedia di laboratorium. Sarana pendukung tersebut memberikan peluang untuk dilakukan model pembelajaran langsung berbasis praktikum.

Siswa sekolah khususnya Madrasah Aliyah (MA) sudah saatnya melakukan analisis terhadap data yang diperoleh dari kegiatan praktikum. Kegiatan tersebut teori yang awalnya telah diperoleh siswa dapat diimplementasikan, dimulai dari mengenal alat-alat praktikum, fungsi dari berbagai alat tersebut sampai kegiatan praktikum dengan memanfaatkan fasilitas yang telah tersedia di laboratorium. Kegiatan praktikum merupakan salah satu kegiatan yang sangat berperan dalam meningkatkan keberhasilan proses belajar mengajar. Kegiatan praktikum menjadi pembelajaran alternatif bagi siswa untuk mengembangkan kemampuan berpikir menganalisis dan memecahkan masalah, membuktikan dan menarik kesimpulan suatu objek dari materi yang dipelajari. Praktikum yang dilakukan di laboratorium dalam pembelajaran memiliki manfaat dan pengalaman yang cukup besar bagi siswa dalam ketiga ranah pembelajaran. Pada ranah kognitif, praktikum di laboratorium memberikan manfaat dalam membantu pemahaman siswa. Pada ranah afektif, praktikum dapat melatih sikap ilmiah siswa. Pada ranah psikomotorik, pelaksanaan praktikum dapat melatih keterampilan siswa dalam menggunakan alat dan bahan (Litasari, 2014).

Pembelajaran langsung adalah suatu model pembelajaran yang bersifat teacher center. Menurut Arends (2012), model pembelajaran langsung adalah salah satu pendekatan mengajar yang dirancang khusus untuk menunjang proses belajar siswa yang berkaitan dengan pengetahuan prosedural dan pengetahuan deklaratif yang terstruktur dengan baik yang dapat diajarkan dengan pola kegiatan yang bertahap, selangkah demi selangkah. Menurut Royani dkk. (2018) model pembelajaran langsung ternyata membantu siswa lebih fokus dan kreatif, sehingga pengetahuan dan keterampilan dapat diterima dan terserap dengan baik oleh seluruh siswa. Agar siswa dapat meningkatkan hasil belajar secara optimal, maka pada penelitian ini menggunakan model pembelajaran langsung berbasis praktikum dengan menerapkan metode praktikum.

Keterampilan dasar yang terkandung dalam keterampilan proses sains merupakan sebuah keterampilan yang diperlukan oleh seseorang untuk melakukan penyelidikan ilmiah, sehingga memudahkan seseorang sebagai siswa di sekolah untuk lebih memahami fenomena atau peristiwa yang terjadi (Septaria dkk., 2019) Keterampilan-keterampilan yang menjadi keterampilan dasar yang diperlukan oleh seseorang saat ini masih belum dilatihkan secara maksimal diberbagai jenjang 
pendidikan di Indonesia, di jenjang sekolah menengah atas juga didapatkan bahwa kemampuan proses sains ketika melaksanakan praktikum dan sebagian besar siswa kurang teliti dalam mengamati dan menyelesaikan permasalahan belum memahami bagaimana petunjuk dari sebuah praktikum (Septaria dkk., 2019). Keterampilanketerampilan dalam keteramppilan proses sains meliputi (1) mengamati, (2) merumuskan masalah (3) menyusun hipotesis, (4) mengidentifikasi variabel, (5) mengkomunikasikan data, dan (6) menyimpulkan data (Nur, 2011; Ibrahim \& Nur, 2010; Mafudi, 2018; Hardiyanti, 2017; Rinanti, 2016).

Menurut Susiwi (2009) keterampilan proses sains terdiri dari aspek proses mengamati, mengklasifikasikan, memprediksi, mengkomunikasikan, mengukur, menyimpulkan. Pengembangan keterampilan proses sains siswa dan penguasaan konsep siswa, dapat menggunakan metode praktikum, karena pada kegiatan praktikum dapat dikembangkan keterampilan psikomotorik, kognitif, dan juga afektif (Wulandari dkk., 2017). Hasil penelitian Royani dkk. (2018) menunjukkan keterampilan proses sains siswa mengalami peningkatan dan secara signifikan berbeda nyata dengan keterampilan proses sains siswa yang dibelajarkan menggunakan pembelajaran konvensional. Hasil penelitian tersebut hanya mengujicobakan pembelajaran langsung berbasis praktikum tanpa mengembangkan LKS. Sejalan dengan hasil penelitian tersebut, Khery dan Khaeruman (2016) menyatakan bahwa keterampilan proses sains mahasiswa dinyatakan berbeda nyata antara kelas eksperimen 1 dan kelas eksperimen 2 yang dibelajarkan menggunakan model pembelajaran context-rich problems berbentuk multimedia interaktif dengan kelas kontrol. Hasil penelitian tersebut menunjukkan pengaruh yang tidak konsisten pada kedua kelas eksperimen karena berbeda nyata. Berdeda dengan hasil penelitian tersebut, Asy'ari et al. (2019) menemukan bahwa keterampilan proses sains mahasiswa calon guru berbeda nyata pada beberapa indikator berdasarkan gender dengan kategori sedang.

Berdasarkan observasi yang dilakukan pembelajaran praktikum di MAPK Syeh Zainuddin Anjani memiliki beberapa permasalahan diantaranya pelaksanaan praktikum tidak didukung karena keterbatasan alat dan ketersediaan bahan pada beberapa materi pelajaran serta, sehingga praktikum materi kultur jaringan belum pernah di praktikkan dan lembar kegiatan siswanya masih sangat sederhana sehingga guru tidak terpacu untuk melakukan praktikum kultur jaringan. Sehingga peneliti mengembangkan Lembar Kegiatan Siswa (LKS) materi kultur jaringan untuk meningkatkan kwalitas belajar berbasis praktikum dengan pelaksanaan praktikum di Laboratorium kultur jaringan hanya ada di Universitas Mataram dan BBI-PPH Narmada untuk daerah Nusa Tenggara Barat yang Khusus di pulau Lombok. Lembar Kerja Siswa (LKS) adalah lembaran-lembaran berisi materi, ringkasan, dan tugas yang harus dikerjakan oleh siswa. Peran Lembar Kerja Siswa (LKS) dalam pembelajaran salah satunya adalah sebagai bahan ajar yang bisa meminimalkan peran pendidik namun lebih mengaktifkan peserta didik (Prastowo, 2011). Penelitian ini bertujuan untuk mengembangkan LKS biologi SMA berbasis praktikum dengan model pembelajaran langsung yang valid, praktis, dan efektif untuk meningkatkan keterampilan proses sains siswa. 


\section{METODE}

Penelitian ini merupakan penelitian pengembangan dengan desain 4D (design, define, develop, dessiminate) (Thiagarajan \& Semmel, 1974) yang menghasilkan produk berupa LKS berbasis praktikum dengan model pembelajaran langsung yang valid, praktid, dan efektif untuk meningkatkan keterampilan proses sains 30 siswa di MAPK Syeh Zainuddin Anjani.

Produk yang dihasilkan divalidasi terlebih dahulu oleh tiga validator yang berkompeten menggunakan lembar validasi dengan meninjau format, isi, Bahasa, dan ilustrasi melalui mekanisme focus group discussion (FGD) menggunakan skala lima. Skor rata-rata penilaian validator dikatedorisasikan menggunakan Tabel 1 berikut. Tabel 1. Kategori penilaian hasil validasi LKS

\begin{tabular}{ll}
\hline Interval & Kategori Penilaian \\
\hline $0,0 \leq \mathrm{SV} \leq 1,0$ & Tidak valid \\
$1,0 \leq \mathrm{SV} \leq 2,0$ & Kurang valid \\
$2,0 \leq \mathrm{SV} \leq 3,0$ & Cukup valid \\
$3,0 \leq \mathrm{SV} \leq 4,0$ & Valid \\
$4,0 \leq \mathrm{SV} \leq 5,0$ & Sangat valid \\
\hline & (diadaptasi Ratumanam \& Laurens, 2006)
\end{tabular}

Kepraktisan produk yang dikembangkan diidentifikasi berdasarkan respon siswa setelah pembelajaran. Respon mahasiswa didefinisikan sebagai tanggapan siswa yang meliputi perhatian, keterkaitan, keyakinan dan kepuasan terhadap LKS yang dikembangkan. Siswa memberikan respon mengenai pembelajaran dengan memilih pernyataan yang sesuai dengan kehendaknya sendiri yang terdiri atas 2 kategori yakni ya dan tidak atau disebut skala Guttman. Siswa menjawab Ya bernilai (1) dan siswa menjawab Tidak bernilai (0). Data dianalisis berdasarkan kelompok responden yang menjawab "Ya" dan kelompok responden yang menjawab "Tidak" meliputi indikator (1) Kemenarikan LKS; (2) Keterbaharuan LKS; (3) Proses pembelajaran; (4) Bahasa; dan (5) Ilustrasi. Secara matematis dapat ditulis sebagai berikut.

$$
P=\frac{\sum K}{\sum N} x 100 \%
$$

Dengan $P$ : persentase skor respon siswa; $\sum K$ : Jumlah siswa yang memilih jawaban $Y a$ atau Tidak; dan $\sum N$ : Jumlah siswa yang mengisi angket.

Persentase respon siswa dikonversi dengan kriteria (1) Angka 0\%-20\%= Sangat lemah; (2) Angka 21\%-40\%= Lemah; (3) Angka 41\%-60\%=Cukup; (4) Angka 61\%$80 \%=$ Kuat; dan (5) Angka 81\%-100\%= Sangat kuat (Riduwan, 2010).

Keefektifan LKS yang dikembangkan diukur menggunakan lembar observasi yang dilakukan oleh dua orang pengamat dengan menilai aktivitas siswa meliputi indikator (1) Mengamati; (2) Menanya; (3) Klasifikasi; (4) Hipotesis; (5) Melakukan percobaan; (6) Menulis hasil percobaan; (7) Implementasi; (8) Kesimpulan; (9) Menerapkan konsep; (10) Komunikasi. Siswa dibagi ke dalam kelompok dalam pembelajaran dan melakukan percobaan untuk mendapatkan data keterampilan proses sains siswa menggunakan skala emapat di mana 1= tidak baik; 2 cukup baik; 3= baik; dan 4= sangat baik. Skor keterampilan proses sains siswa selanjutnya dikonversi berdasarkan persentase seperti disajikan pada Tabel 2 berikut. 
Tabel 2. Kriteria keterampilan proses sains

\begin{tabular}{ll}
\hline Interval $(\%)$ & Kategori Penilaian \\
\hline $0-24$ & Tidak baik \\
$25-49$ & Cukup \\
$50-74$ & Baik \\
$75-100$ & Sangat baik \\
\hline
\end{tabular}

\section{HASIL DAN PEMBAHASAN}

Lembar kerja siswa (LKS) yang telah disusun menggunakan metode pembelajaraan langsung kemudian divalidasi oleh validator. Hasil validasi LKS terdapat 4 aspek yang dinilai oleh validator, yaitu: (1) format LKS; (2) Isi LKS; (3) bahasa LKS; dan (4) ilustrasi LKS, Hasil validasi bisa dilihat pada Tabel 3.

Tabel 3. Hasil Validasai LKS Biologi SMA berbasis praktikum dengan metode pembelajaran langsung berbasis keterampilan proses sains

\begin{tabular}{lrrlll}
\hline Instrumen & & $\begin{array}{l}\text { Indikator } \\
\text { LKS }\end{array}$ & $\begin{array}{l}\text { Rata-rata } \\
\text { aspek }\end{array}$ & Validasi & Kategori \\
\hline Lembar & Kerja $\quad$ Siswa & Format & 3,6 & & \\
berbasis & keterampilan & Isi & 3,7 & 3,9 & Cukup Valid \\
proses & & Bahasa & 3,9 & & \\
& & Ilustrasi & 4,3 & & \\
& & & & &
\end{tabular}

Berdasarkan Tabel 3 Lembar Kerja Siswa berbasis keterampilan proses sains dengan indikator format dengan rata-rata 3,6 indikator isi 3,7 indikator bahasa 3,9 dan indikator ilustrasi 4,3 dengan hasil validasi keseluruhan indikator mencapai 3,9 sehingga dapat disimpulkan Lembar Kerja Siswa berbasis keterampilan proses sains cukup valid untuk digunakan sebagai bahan ajar yang inovatif, sehingga digunakan untuk uji coba terbatas di MAPK Syeh Zainuddin Anjani.

Kepraktisan LKS yang dikembangkan ditinjau dari respon siswa setelah pembelajaran. Data hasil respon siswa dapat dilihat pada Tabel 4.

Tabel 4. Data hasil respon siswa yang menggunakan LKS Biologi SMA berbasis praktikum dan keterampilan proses sains siswa MAPK Syeh Zainuddin Anjani

\begin{tabular}{llll}
\hline No & Aspek & Kategori $(\%)$ \\
\hline 1 & Kemenarikan LKS & Senang $(95,5)$ & Tidak senang $(4,5)$ \\
2 & Kebaruan LKS & Baru $(83,6)$ & Tidak baru $(16,4)$ \\
3 & Proses pembelajaran & Berminat $(93)$ & Tidak berminat $(7)$ \\
4 & Bahasa & Mudah $(95)$ & Sulit $(5)$ \\
5 & Ilustrasi & Senang $(98)$ & Tidak senang $(2)$ \\
\hline
\end{tabular}

Berdasarkan Tabel 4 siswa merespon sangat baik atas LKS Biologi SMA berbasis praktikum dilihat dari kemenarikan LKS yang mendapatkan persentase senang sebanyak 95,5\%, keterbaharuan LKS sebanyak 83,6\%, proses pembelajaran berminat 93\%, bahasa 95\%, dan ilustrasi 98\%. Sesuai penelitian Zulhelmi (2009) bahwa respon siswa merupakan tanggapan dan aktivitas yang diberikan selama pembelajaran, melalui pendekatan pembelajaran setelah melakukan dan mengamati aktivitas 
dengan menggunakan panca indra. keterampilan proses sains dapat dilihat pada Tabel 5.

Tabel 5. Persentase keterampilan proses sains dengan metode pembelajaran langsung berbasis praktikum

\begin{tabular}{lllllll}
\hline No & $\begin{array}{l}\text { Indikator keterampilan } \\
\text { proses }\end{array}$ & P1 (\%) & P2 (\%) & P3 (\%) & Rerata (\%) & Kategori \\
\hline 1 & Mengamati & 82,33 & 82 & 87 & 83,78 & Baik \\
2 & Menanya & 80,23 & 77 & 84 & 80,41 & Baik \\
3 & Klasifikasi & 88,20 & 88 & 92 & 89,4 & Baik \\
4 & Hipotesis & 90,25 & 95 & 85 & 90,01 & Baik \\
5 & Melakukan percobaan & 77,20 & 86,50 & 89 & 84,23 & Baik \\
6 & Menulis hasil percobaan & 95,90 & 93,70 & 96 & 95,2 & Baik \\
7 & Implementasi & 92,90 & 80 & 90 & 86,63 & Baik \\
8 & Kesimpulan & 93,13 & 92 & 93 & 92,71 & Baik \\
9 & Menerapkan konsep & 87,80 & 86,20 & 88 & 87,33 & Baik \\
10 & Komunikasi & 95,20 & 96,20 & 96,30 & 95,9 & Baik \\
\hline
\end{tabular}

Data persentase keterampilan proses sains pada Tabel 5 menunjukkan bahwa semua indikator termasuk pada kategori sangat baik, mulai dari mengamati, menanya, klasifikasi, hipotesis, melakukan percobaan, menulis hasil percobaan, implementasi, kesimpulan, menerapkan konsep dan komunikasi menunjukkan bahwa LKS berbasis keterampilan proses sains dan bebpikir kritis siswa dapat meningkatkan keterampilan proses sains siswa. Keterampilan proses siswa akan semakin tinggi jika semakin tinggi keterlibatan siswa dalam praktikum dan kegiatan ilmiah lainnya. Sejalan dengan penelitian Rahayu (2011) bahwa pendekatan keterampilan Proses yang merupakan pembelajaran penelitian dapat meningkatkan potensi siswa dalam proses sains dan sikap ilmiah.

\section{KESIMPULAN}

Berdasarkan hasil penelitian dapat diketahui bahwa LKS biologi SMA berbasis praktikum dengan model pembelajaran langsung yang dikembangkan dinyatakan valid, praktis, dan efektif untuk meningkatkan keterampilan proses sains siswa kelas X1 IPA 1 MAPK Syeh Zainuddin Anjani.

\section{SARAN}

Penelitian ini hanya terbatas pada keterampilan proses sains yang diamati selama proses pembelajara, baik itu proses praktikum dan komunikasi hasil praktikum, sehingga penting untuk melakukan penelitian terkait ketrampilan proses sains siswa ditinjau dari kognitif pada masa mendatang.

\section{UCAPAN TERIMA KASIH}

Penelitian ini tidak menerima hibah khusus dari agensi pendanaan mana pun di sektor publik, komersial, atau nirlaba.

DAFTAR PUSTAKA

Arends, R. I. (2012). Learning to teach. New York: McGraw-Hill Companies. 
Asy'ari, M., Fitriani, H., Zubaidah, S., \& Mahanal, S. (2019). The Science Process Skills of Prospective Biology Teachers in Plant Cell Material Based on Gender. International Journal of Emerging Technologies in Learning (iJET), 14(19), 168178.

Hardiyanti, P. C. (2017). Keefektifan Model Problem Based Learning Untuk Meningkatkan Keterampilan Proses Sains Siswa . Jurnal Inovasi Pendidikan Kimia, 1862-1671.

Ibrahim, M., \& Nur, M. (2010). Dasar-dasar proses belajar mengajar. Surabaya: Unesa University Press.

Kemendikbud. (2013). Peraturan menteri pendidikan dan kebudayaan nomor 69 tentang kerangka dasar dan struktur kurikulum sekolah menengah atas/madrasah aliyah. Jakarta: Kemendikbud.

Khery, Y., \& Khaeruman. (2016). Pengaruh Context-Rich Problems Berbentuk Multimedia Interaktif terhadap Keterampilan Proses Sains, Sikap Ilmiah, dan Pemahaman Konsep. Prisma Sains: Jurnal Pengkajian Ilmu dan Pembelajaran Matematika dan IPA IKIP Mataram, 4(2), 83-93.

Litasari, K. N., Setiati, N., \& Herlina, L. (2014). Profil Pembelajaran Biologi Berbasis Laboratorium dan Implikasinya Terhadap Hasil Belajar Siswa di SMA Negeri SeKabupaten Semarang. Unnes Journal of Biology Education. 3(2), 172179.

Mafudi, I. (2018). Profil Analisis Kebutuhan Pengembangan Media Praktikum Gerak Lurus Untuk Meningkatkan Keterampilan Proses Sains. Seminar Nasional Quantum \#25 (Pp. 223-227). Yogyakarta: Universitas Ahmad Dahlan (Uad).

Nur, M. (2011). Strategi-strategi Belajar. Surabaya: Pusat Sains dan Matematika Sekolah Unesa.

Prastowo, A. (2011). Panduan Kreatif Membuat Bahan Ajar Inovatif. Yogyakarta: DIVA Press.

Rahayu, E. (2011). Pembelajaran Sains dengan Pendekatan Keterampilan Proses untuk meningkatkan Hasil Belajar da kemampuan Berpikir Kreatif Siswa. Jurnal Pendidikan Fisika Indonesia. 7(1), 33-37.

Riduwan. (2010). Skala pengukuran variabel-variabel penelitian. Bandung: Alfabeta.

Rinanti, H. R. (2016). Proses Pembelajaran Model Pair Checks Untuk Meningkatkan Keterampilan Proses Sains Siswa Smp. Unnes Physics Education Journal, 54-59.

Royani, I., Mirawati, B., \& Jannah, H. (2018). Pengaruh Model Pembelajaran Langsung Berbasis Praktikum Terhadap Keterampilan Proses Sains dan Kemampuan Berpikir Kritis Siswa. Prisma Sains: Jurnal Pengkajian Ilmu dan Pembelajaran Matematika dan IPA IKIP Mataram, 6(2), 46-55.

Septaria, K., Dewanti, B., A., \& Habibbulloh, M. (2019). Implementasi Metode Pembelajaran Spot Capturing Pada Materi Pemanasan Global untuk Meningkatkan Keterampilan Proses Sains. Prisma Sains : Jurnal Pengkajian Ilmu dan Pembelajaran Matematika dan IPA IKIP Mataram, 7(1), 27-37. doi:https://doi.org/10.33394/j-ps.v0i0.1379

Susiwi. (2009). Analisis Keterampilan Proses Sains Siswa SMA Pada Model Pembelajaran Praktikum DEi. Hd, Jurnal Pengajaran MIPA, 3(1), 33-37. 
Thiagarajan \& Semmel. (1974). Instructional Development for Training Teachers of Exceptional Children; A Source Book. Indiana: Indiana University.

Wulandari, V., C., P., Masjhudi., \& Balqis. (2017). Penerapan Pembelajaran Berbasis Praktikum Untuk Meningkatkan Keterampilan Proses Sains Dan Penguasaan Konsep Siswa Kelas XI IPA 1 di SMA Muhammadiyah 1 Malang. Universitas Negeri Malang.

Zulhelmi. (2009). Penilaian Psikomotor dan Respon Siswa dalam Pembelajaran Sains Fisika Melalui Penerapan Penemuan Terbimbing di SMP Negeri 20 Pekanbaru. Jurnal Geliga Sains, 3(2),8-13. 